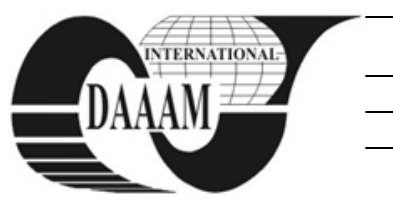

Annals of DAAAM for 2011 \& Proceedings of the 22nd International DAAAM Symposium, Volume 22, No. 1, ISSN $1726-9679$ ISBN 978-3-901509-83-4, Editor B. Katalinic, Published by DAAAM International, Vienna, Austria, EU, 2011 Make Harmony between Technology and Nature, and Your Mind will Fly Free as a Bird Annals \& Proceedings of DAAAM International 2011

\title{
PROPOSAL OF PRODUCTION OPTIMIZATION IN THE ENTERPRISE
}

\author{
MALEGA, P[eter] \& SPISAK, E[mil]
}

\begin{abstract}
The goal of this paper is to describe the necessary changes that have to been made to improve production or to optimize the whole production process. The article is divided into three main parts. The first part is about the approaches in production optimization. The second part describes the production process in the specific business. The third part discusses the major detected problems in the business and the solutions for production optimization.

Key words: optimization, production process, business, enterprise, workplace, manufacturing, material, management, calculation, support, knives gringing
\end{abstract}

\section{INTRODUCTION}

Enterprise is the fundamental element of the economy and the goal of the enterprise is to prosper, so make the profit (Popčáková, 2011). For each business, it is necessary to identify their strengths and weaknesses based on the analysis and search options to consolidate and develop its position (Feylizadeh \& Bagherpour, 2011); Fletcher, 2000)

\section{PRODUCTION OPTIMIZATION}

Due to the inherently rigid nature of optimization models, it is not possible to develop a generic model that could accommodate all scenarios (Knežo; Kováč \& Líška, 2002). Shanthikumar and Sargent (1983) discussed an integrated approach namely hybrid simulation/analytical modelling tempting to use advantages of both simulation and analytical modelling through the unique system. Byrne and Bakir (1999) developed the hybrid algorithm by combining mathematical programming and simulation model of the manufacturing system. Then, Kim and Kim (2001) proposed the extended linear programming model for hybrid problems. Byrne and Hossain (2005) proposed the extended linear programming model over (Byrne and Bakir, 1999; Kim and Kim, 2001). In their model, in order to introduce the unit load concept of JIT, work load of jobs was sub-divided (Tayfur, 1996). In considering project and production principles through the analyzing unique system, Noori et al. (2008) proposed the fuzzy control chart application to MPMP problems (Spišáková, 2008).

\section{DESCRIPTION OF PRODUCTION PROCESS}

Observed enterprise is located in Košice (Slovakia). It was set up in 1998 as the joint-stock company and is engaged in longitudinal and transverse cutting of sheet. This enterprise use dividing lines from SACMA. Scheme of the present production workplace is shown in Fig. 1. The whole process in the observed enterprise begins with the production facilities introduced into material deposited on vertical or horizontal axis. Material should be kept in storage before dividing lines. There each roll is labelled, which lists all the parameters such as size, gross weight, net weight, brand type of material, owner of the material and its original code, under which any material can be identified. Based on the order it is created the job card, which lists all the coils to split. In the production order it is listed the original number of each coil, material thickness, roll width, shear plan, thickness and width of the tape tolerance, trimmed material and the theoretical amount of scrap, which is created. Based on the production order, it is set the "support", which is the part of the line on which are placed dividing circular knives. Parts of the line are almost ever two "supports". This happens because of the fact that one is used to operate in the divided plate line, the second slide used to prepare the plan, according to the further shear (Panneerselvam, 2010).

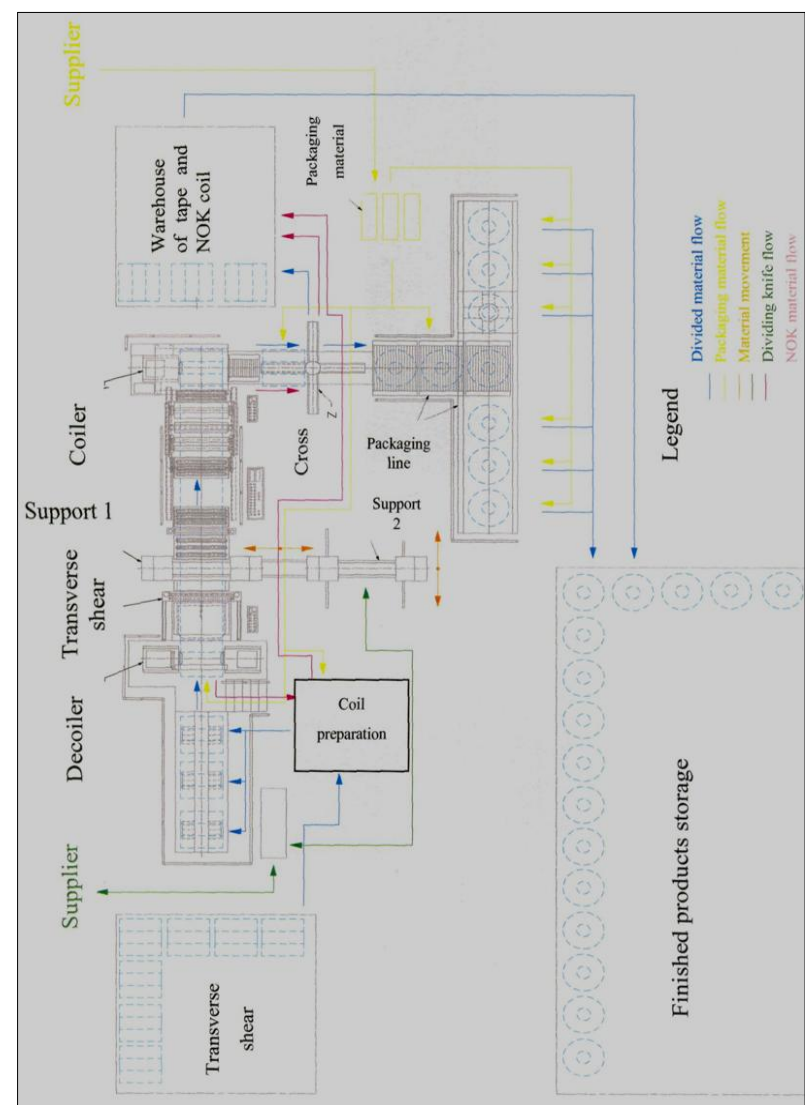

Fig. 1. Scheme of the production workplace (Panneerselvam, 2010)

When the new "support" is prepared and previous order is finished, than will be prepared rolls, which are intended for further processing of next order. Then the coil is placed at one of three stands that are before the line. From this point, the scroll through the sliding carriage moves to decoiler (Spišáková, 2008). Consequently, the coil is clamped in the jaws and the whole decoiler is centred in regard of other parts of the line. The part of the coil is introduced into the transverse shear, where is tagged the beginning of the coil, which is 
usually damaged because of transport and handling. In this phase it is also transmitted the thickness measurement and material should be introduced into the "support" until the thickness is not according to customer requirements. If after tag of the coil round $2 \%$, is the thickness still don't correct, scroll will be shut down and this should notify the customer, who decides what will follow with coils in the next time. Subsequently, the coil is introduced into the longitudinal shear ("support"), with scissors sets overlap. Material then must have the desired cutting area of sufficient quality. Then the next step is the measuring of the tape using callipers. Furthermore, the coil is introduced into the other parts of the line until the coiler, where the end of the tape is mounted in the jaws (Panneerselvam, 2010). Once the tapes are mounted in the jaws, than release the reel brake and brake lines cross. Then the whole division has provided with rollers, which pulls the entire mass of the coil and wound the divided tape. After dividing process the end of the tapes are aligned, which also separates the material damaged in the roll. Through the displacement piston are tapes moved to the trolley, in which individual bands are taped by edging strip to avoid deployment. Then the tapes are moved to the cross. At this point, the belt are packed by transverse strips and transferred to the warehouse of finished products, or tape is moved into the packing line, where each strip is turned to the vertical axis and then is packed by transverse bands to the prepared palette storage.

\section{PRODUCTION OPTIMIZATION PROPOSAL}

As the major problem areas in the selected business can be considered: knives grinding, lack of oil equipment, scrap storage, high maintenance costs, cooperation with customers, monitoring of material under complaint. Due to the character of this paper, in this section, we will specify the steps to improve the knives grinding.

Dividing knives are the important part of the manufacturing enterprise. The knives are in very small number and it is not possible to share some shear plans, respectively if the knives are worn, it is not possible to use knives at all. It is mainly the shear plan, in which is necessary to divide the large number of rolls of tape. In this process it is necessary to use the one set of knives. The combination of different sets of knives is not allowed because of different external diameters. The condition of the same diameter knives for splitting has to be observed, because there is even spacing across the width of the tape rolls. This condition can then be observed also for grinding and it is important to grind once the whole set of knives. The selected business use three sets of knives to divide, which are colour coded for ease of their recognition. To achieve the longest life of the knife, blade manufacturer determined the frequency of grinding. The knives are grinded after processing about 2000 tons of material in their proper use. This means that, if one knife has been selected from the set and was used to divide the quantity of material, the whole set is sent for grinding.

In this time the sharpening of knives is provided by the external company, which is the specialist in this activity. Because the amount of divided material is 75000 tonnes, it is forced to send the knives 36 times for grinding, which ultimately presents wasted repeatedly direct annual cost of knives grinding. Another advantage of grinding knives at their own expense is the check of the grinding and the conditions of grinding. When the business has problems with it, there is the risk of burning knives. This fact is hardly detectable. In the dividing process there is very fast wear and split and thus degrades the material, and then the value of the enterprise must bear. Excluding the cost of grinding this further increase the total costs (about the cost of split and damaged material), but then it also destroys the knives and their total lifetime is reduced. Also the business will be forced to buy the new set of knives rather than knives had been grind properly. Scheme of the workplace after proposed measurements is shown in Fig. 2. In this Fig. 2 is added also the oil equipment, because except knives grinding, either the oil equipment could help to optimize the whole process.

Following calculation of the proposed change the enterprise could reduce their costs and the pay-back period of investment could be round one year.

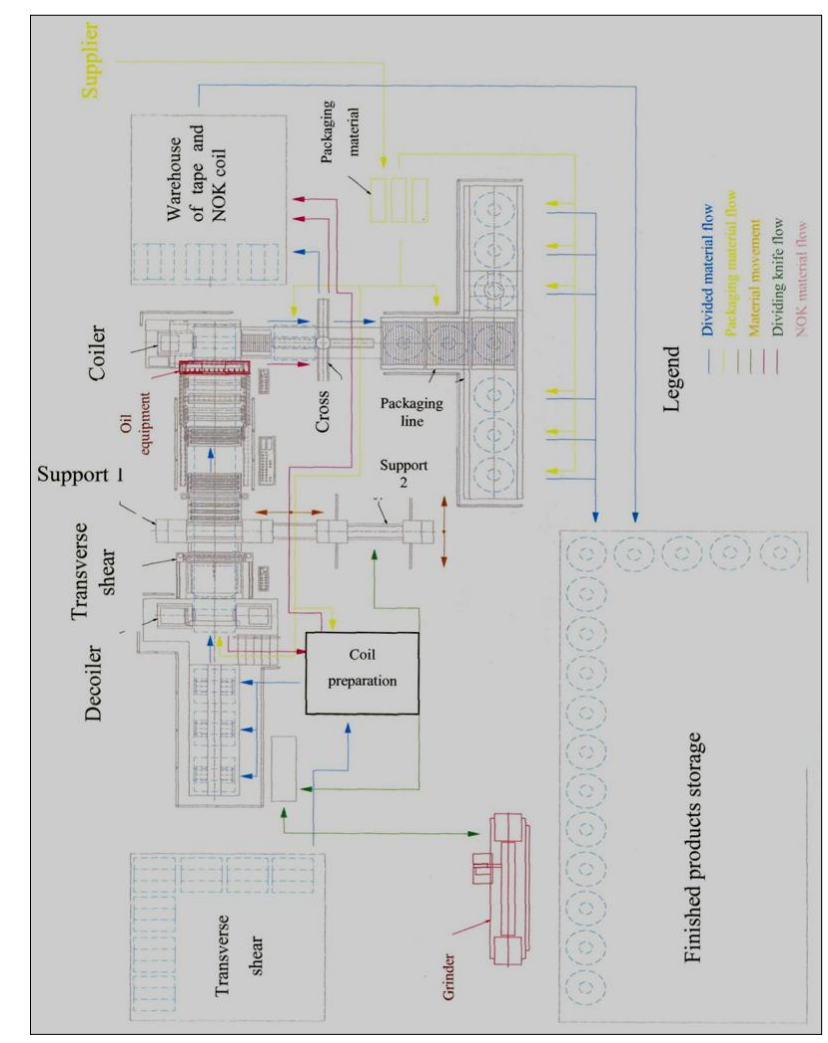

Fig. 2. Scheme of the proposed workplace

\section{CONCLUSION}

The production optimization should be the one of the strategic corporate objectives, because in today's competition conditions the optimal production can provide business the competitive advantage.

\section{REFERENCES}

Feylizadeh, M. R.; Bagherpour, M. (2011). Application of Optimization Techniques in Production Planning Context: A Review and Extension. International Journal of Manufacturing Systems, Vol. 1, No. 1, p. 1-8. ISSN: 21521921

Fletcher, R. (2000). Practical Methods of Optimization - 2 edition. Wiley, ISBN: 047191547 5, Dundee

Knežo, D.; Kováč, J.; Líška, O. (2002). Znižovanie rizika v projektovaní automatizáciou rozhodovacích procesov, In: Acta Mechanica Slovaca - Principia cybernetica, Vol. 6, No. 2, , p. 223-230. ISSN 1335-2393.

Panneerselvam, R. (2010). Production and operations management. Phi Learning. ISBN: 8120327675

Popčáková, M. (2011). Optimalizácia vo výrobnom podniku prostredníctvom nákladového retazca. Diploma work. Technical university, Faculty of Mechanical Engineering, 72 p. Košice

Spišáková, E. (2008). Typy inovácií a ich zavádzanie v podnikoch SR. In: Transfer inovácií. Vol. 10, No. 11, p. 222-225., <http://www.sjf.tuke.sk/transferinovacii/> ISSN 1337-7094.

Tayfur A. (1996). Performance Analysis of Manufacturing systems. Springer-Verlag, ISBN 0-387-94773-6 